\title{
Prevalence of sulfate reducing bacteria in oral cavity: a narrative review
}

\author{
${ }^{1}$ Gopalakrishnan, U., ${ }^{2 *}$ Felicita, A. S., ${ }^{1}$ Mahendra, L., ${ }^{3}$ Premkumar, S., and \\ ${ }^{3}$ Madasamy, R. \\ ${ }^{1}$ Department of Orthodontics and Dentofacial Orthopaedics, Sri Venkateswara Dental College and \\ Hospitals, Thalambur, T. N., India \\ ${ }^{2}$ Department of Orthodontics and Dentofacial Orthopaedics, Saveetha Dental College, Saveetha \\ University, Chennai \\ ${ }^{3}$ Department of Orthodontics and Dentofacial Orthopaedics, T. N. Government Dental \\ College and Hospital, Chennai \\ *Correspondence to: sumifeli@hotmail.com
}

\begin{abstract}
:
Sulphate is used as terminal electron acceptor for the respiration of sulphate reducing bacteria (SRB) forming a specialized group of microbes. SRB have been known to cause microbiologically induced corrosion by forming metallic sulfides and oxides in the process of their dissimilatory respiration. Since oral cavity provides a conducive environment for corrosion, presence of SRB in oral cavity and their corrosive potential needs to be assessed. This article provides a narrative review of the available literature with the primary objective of evaluating the presence of SRB in oral cavity of patients.
\end{abstract}

Keywords: SRB; corrosion, oral cavity, patients

Received February 8, 2019; Revised February 18, 2019; Accepted February 20, 2019

Copyright 2019 AJCEM Open Access. This article is licensed and distributed under the terms of the Creative Commons Attrition 4.0 International License (http://creativecommmons.org/licenses/by/4.0), which permits unrestricted use, distribution and reproduction in any medium, provided credit is given to the original author(s) and the source.

\section{Prévalence des bactéries sulfato-réductrices dans la cavité buccale: bilan narratif}

\author{
${ }^{1}$ Gopalakrishnan, U., ${ }^{2 *}$ Felicita, A. S., ${ }^{1}$ Mahendra, L., ${ }^{3}$ Premkumar, S., and \\ ${ }^{3}$ Madasamy, R. \\ ${ }^{1}$ Département d'orthodontie et d'orthopédie dentofaciale, Collège dentaire et hôpitaux Sri \\ Venkateswara, Thalambur, T. N., Inde \\ ${ }^{2}$ De département d'orthodontie et d'orthopédie dentofaciale, Saveetha Dental College, Université de \\ Saveetha, Chennai \\ ${ }^{3}$ De département d'orthodontie et d'orthopédie dentofaciale, T. N. Collège dentaire et hôpital public, \\ Chennai \\ * Correspondance à: sumifeli@hotmail.com
}




\begin{abstract}
Abstrait:
Le sulfate est utilisé comme accepteur d'électrons terminal pour la respiration des bactéries réductrices de sulfate (SRB) formant un groupe spécialisé de microbes. On sait que le SRB provoque une corrosion induite par la microbiologie en formant des sulfures et des oxydes métalliques au cours du processus de respiration dissimilatoire. Étant donné que la cavité buccale crée un environnement propice à la corrosion, la présence de SRB dans la cavité buccale et leur potentiel corrosif doivent être évalués. Cet article fournit une revue narrative de la littérature disponible avec l'objectif principal d'évaluer la présence de SRB dans la cavité buccale des patients
\end{abstract}

Mots-clés: SRB; corrosion, cavité buccale, patients

\section{Introduction:}

Microorganisms play an important part in sulphur transformations. Sulphur which occurs in nature as pyrite, gypsum or sulphate is either taken up as a nutrient for metabolic energy such as sulphide oxidation by chemolithotropic sulphur bacteria and dissimilatory sulphate reduction by sulphate-reducing bacteria (SRB) or for producing sulphur containing amino acids or enzymes. SRB have been known to cause microbiologically induced corrosion by forming metallic sulfides and oxides in the process of their dissimilation $(1,2,3)$. In accordance with this, the role of SRB in causing metal corrosion is of important concern in oral cavity where a lot of metallic components are used.

Assessing the prevalence of SRB in oral cavity is of utmost importance with reference to the same. This article provides a narrative review of the available literature with the primary objective of evaluating the presence of SRB in oral cavity of patients.

\section{Materials and methods:}

We searched PubMed and Embase databases. The search covered the period 1980 to March 2018. The main terminologies used for search were; "sulfate reducing bacteria and oral or dental or periodontal or saliva" AND "presence or prevalence of SRB and oral or dental or periodontal or saliva". We identified 123 articles in PubMed and 26 in Embase with these key words. Of these, 78 articles were selected after eliminating duplications. These 78 articles were screened and 68 articles were eliminated based on relevancy. The remaining 10 articles were further scrutinized and the article by Costinar et al., (4) was eliminated since it was related to dogs' oral cavity. The remaining 9 articles were included in the review (Fig 1).

\section{Results:}

\section{Description of studies}

Nine articles were finally selected for inclusion in the review. There were two major population groups studied, one involved healthy oral cavity and the other periodontally compromised. One article by Paster et al., (7) included samples from refractory periodontitis, acute necrotizing ulcerative gingivitis (ANUG) and HIV patients in addition to healthy and periodontitis patients. The sample size varied from 5 to 118 . The details of the study representing the sample size, sampling sites and percentage of prevalence are given in Table 1.

\section{Sampling sites and methods}

The sampling sites were dorsum of tongue both anterior and posterior, palate, buccal mucosa, vestibular mucosa, supra and subgingival plaque for healthy patients. For periodontitis cases, the samples were taken from the deepest pocket. In the studies by Heggendorn et al., $(5,6)$, sampling was done on saliva in one study and from tooth fragment in another study. The samples were placed in reduced medium to facilitate the survival and growth of anaerobic bacteria in all of the studies with Postgate medium $\mathrm{E}$ being the most being the most common choice 


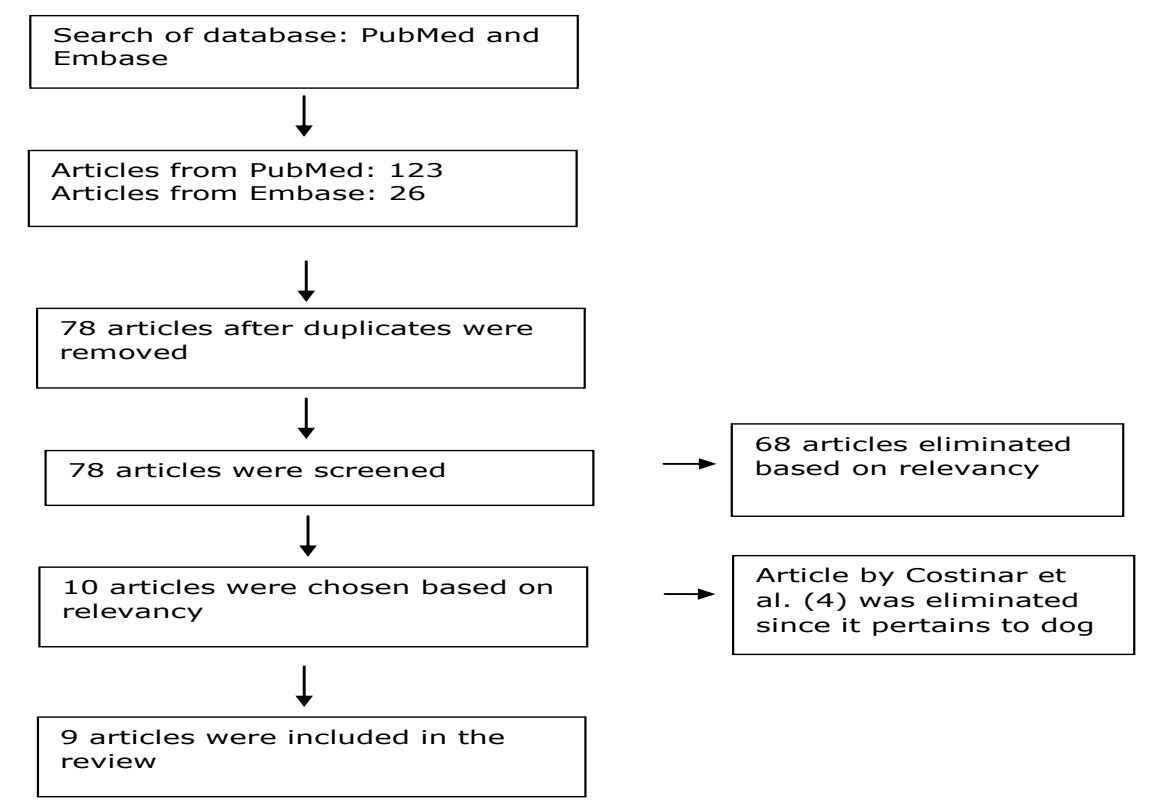

Fig 1: Flowchart for search and selection process

Table 1: List of articles selected for review

\begin{tabular}{|c|c|c|c|c|}
\hline Study & $\begin{array}{l}\text { Sample } \\
\text { size }\end{array}$ & Groups & Sampling sites & Prevalence rate \\
\hline $\begin{array}{l}\text { Paster et al., } \\
2001\end{array}$ & 31 & $\begin{array}{l}\text { Healthy (5) } \\
\text { Periodontitis (9) } \\
\text { Refractory } \\
\text { periodontitis (11) } \\
\text { ANUG(4) } \\
\text { HIV (2) }\end{array}$ & $\begin{array}{l}\text { Subgingival plaque } \\
\text { from four most } \\
\text { diseased or deepest } \\
\text { site }\end{array}$ & $\begin{array}{l}\text { Percentage not given } \\
\text { but positive in } \\
\text { periodontitis, } \\
\text { refractory } \\
\text { periodontitis and } \\
\text { ANUG cases }\end{array}$ \\
\hline $\begin{array}{l}\text { Heggendorn et } \\
\text { al., } 2013\end{array}$ & 118 & $\begin{array}{l}\text { Healthy and } \\
\text { periodontitis with } \\
\text { other subgroups of } \\
\text { gastritis, diabetes }\end{array}$ & Saliva & $29.66 \%$ \\
\hline $\begin{array}{l}\text { Heggendorn et } \\
\text { al., } 2014\end{array}$ & 8 & $\begin{array}{l}\text { Healthy and } \\
\text { periodontitis }\end{array}$ & $\begin{array}{l}\text { Tooth fragment } \\
\text {, healthy tooth } \\
\text { extracted tooth for } \\
\text { orthodontic purpose }\end{array}$ & $37.5 \%$ \\
\hline $\begin{array}{l}\text { Langendijk et al., } \\
1999\end{array}$ & 41 & $\begin{array}{l}\text { Healthy and } \\
\text { periodontitis }\end{array}$ & $\begin{array}{l}\text { Pooled sample from } \\
\text { posterior anterior } \\
\text { palate, vestibular } \\
\text { mucosa, dorsum of } \\
\text { tongue, supragingival } \\
\text { area, around the } \\
\text { opening of parotid } \\
\text { duct, gingival sulci } \\
\text { deep pockets }\end{array}$ & $\begin{array}{l}\text { Site wise: } 10 \% \text { in } \\
\text { mucosa of healthy } \\
\text { and periodontitis, } \\
22 \% \text { for tongue and } \\
\text { supragingival, } \\
86 \% \text { for periodontal } \\
\text { pockets }\end{array}$ \\
\hline $\begin{array}{l}\text { Langendijk et al., } \\
2001\end{array}$ & 168 & $\begin{array}{l}\text { Periodontal SRB } \\
\text { compared with } \\
\text { other spirochetes }\end{array}$ & Subgingival plaque & $\begin{array}{l}\text { SRB and } \\
\text { Porphyromonas co- } \\
\text { existed in } 32 \% \text { cases }\end{array}$ \\
\hline $\begin{array}{l}\text { van der Hoeven } \\
\text { et al., } 1995\end{array}$ & 43 & Periodontitis & Subgingival plaque & $58 \%$ had SRB \\
\hline $\begin{array}{l}\text { Langendijk et al., } \\
2001\end{array}$ & 83 & Periodontitis & $\begin{array}{l}\text { Deepest area of the } \\
\text { pocket }\end{array}$ & $\begin{array}{l}49 \% \text { patients had } \\
\text { SRB }\end{array}$ \\
\hline Willis et al., 1995 & 12 & Healthy & $\begin{array}{l}\text { Posterior and anterior } \\
\text { tongue, mid buccal } \\
\text { mucosa, vestibular } \\
\text { mucosa, supra and } \\
\text { subgingival plaque }\end{array}$ & $83 \%$ \\
\hline $\begin{array}{l}\text { Vianna et al., } \\
2008\end{array}$ & 102 & $\begin{array}{l}\text { Healthy and } \\
\text { periodontitis }\end{array}$ & Subgingival plaque & $\begin{array}{l}41.2 \% \text { in periodontitis } \\
\text { patients, insignificant } \\
\text { presence in healthy }\end{array}$ \\
\hline
\end{tabular}




\section{Description of outcome}

Of the nine studies, seven gave the percentage prevalence of SRB in healthy and periodontitis patients, while the study by Paster et al., (7) reported the prevalence of SRB in association with periodontitis, refractory periodontitis, ANUG and HIV patients. The study by Langendijk et al., (8) assessed the co existence of SRB and Porphyromonas gingivalis in periodontitis patients.

Saliva: One study did the sampling on saliva (5). Of 118 saliva samples collected, 35 were positive for the presence of SRB. Three positive samples were randomly chosen to identify the species of SRB by PCR and sequencing. The three selected samples were identified as Desulfovibrio fairfieldensis, Desulfovibrio desulfuricans and Raoultella ornithinolytica.

Pooled sample: Two of the studies $(9,10)$ did a pooled sampling from posterior and anterior tongue, mid buccal mucosa, vestibular mucosa, supra and subgingival plaques. The study by Langendijk et al., (9) reported site-wise prevalence of $10 \%$ in mucosa of healthy and periodontitis, $22 \%$ for tongue and supragingival, and $86 \%$ for periodontal pockets.

Subgingival: The study by Langendijk et al., (8) reported a prevalence percentage of $32 \%$ along with co-existence with Porphyromonas gingivalis. Van der Hoeven et al., (11) reported $58 \%$ for subgingival plaque. Vianna et al., (12) reported a prevalence of $41.2 \%$ in periodontitis patients while insignificant presence in healthy persons.

Deep pockets: Langendijk (13) reported a prevalence of $49 \%$ for deep pockets.

\section{Discussion}

In this narrative review, we included nine articles describing the presence of SRB in oral cavity of healthy and periodontitis individuals. Almost all the articles have reported positively on the existence of SRB in oral cavity. Though the presence is more in periodontitis patients, healthy individuals also had presence of SRB. This has an important relevance since SRB has been associated with biological corrosion $(1,2,3)$.

SRB are anaerobic microorganisms that are widespread in anoxic habitats, where they use sulphate as a terminal electron acceptor for the degradation of organic compounds, resulting in the production of sulphide (10). The sulphate ion acts as an oxidizing agent for the dissimilation of organic matter in sulphate reduction process like oxygen in conventional respiration. Under anaerobic conditions, a metal surface acts as the anode in an electrochemical reaction and is oxidized, yielding $\mathrm{Me}^{2+}$ ions. Bacteria produce $\mathrm{S}^{2-}$ ions, which enter into a reaction with $\mathrm{Me}^{2+}$ ions, resulting in the formation of metal sulfide. In the cathode area, $\mathrm{H}^{+}$ions are produced and they react with hydroxyl groups. As a result, oxygen from sulfates is consumed for oxidizing metals which leads to the formation of metal oxides thereby corroding metals.

It has been documented that SRBs are capable of corroding metals like stainless steel and titanium intraorally $(14,15)$. There are very few literatures assessing the prevalence of SRB in oral cavity. More studies with larger sample size and randomized controlled trials (RCTs) are needed to have a clear understanding of the prevalence of SRB in oral cavity whether in healthy or periodontitis patients. With SRB being associated with microbiologically induced corrosion, it becomes even more relevant due to the use of metallic implants and other metallic materials in the oral cavity. 


\section{Conclusion}

SRB is present in the oral cavity of both healthy and periodontitis patients but more commonly in periodontitis patients compared to healthy persons. The prevalence rates varied with studies. With the current knowledge on the prevalence of SRB in oral cavity, more quality studies, preferably RCTs with large sample size are needed in the future to evaluate the corrosive potentials of SRB on the metallic materials used intraorally.

\section{References:}

1. Iverson, W. P. Microbial corrosion of metals. Advances in applied Microbiology. 1987;

32: 1 - 36

2. Enning, D., and Garrelfs, J. Corrosion of Iron by Sulfate-Reducing Bacteria: New Views of an Old Problem. Applied and Environmental Microbiology. 2014; 80(4): 1226-1236

3. Muyzer, G., and Stams, A. J. "The ecology and biotechnology of sulphate-reducing bacteria". Nature Reviews Microbiology. 2008; 6: 441-454

4. Costinar, L., Herman, V., and Pascu, C. The presence of sulfate-reducing bacteria in dog's oral cavity. Lucrări Stiinłifice Medicină Veterinară. 2010; 43 (1):

5. Heggendorn, F. L., Gonçalves, L. S., Dias, E. P., Junior, A. S., Galvão, M. M., and Lutterbach, M. T. S. Detection of sulphatereducing bacteria in human saliva. Acta Odontologica Scandinavica, 2013; 1-6 (early online)

6. Heggendorn, F. L., Gonçalves, L. S., Dias, E. P., Heggendorn, C., and Lutterbach, M. T. S. Detection of Sulphate Reducing Bacteria and Others Cultivable Facultative Bacteria in Dental Tissues. Acta Stomatol Croat. 2014; 48(2): 116-122.

7. Paster, B. J., Boches, S. K., Galvin, J. L., Ericson, R. E., Lau, C. N., Levanos, V. A.,
Sahasrabudhe, A., and Dewhirst, F. E. Bacterial Diversity in Human Subgingival Plaque. Journal of Bacteriology. 2001; 183 (12): 3770-3783.

8. Langendijk-Genevaux, P. S., Grimm, W D., and van der Hoeven, J. S. Sulfatereducing bacteria in relation with other potential periodontal pathogens J. Clin. Periodontol. 2001; 28 (12): 1151-1517.

9. Langendijk, P. S., Hagemann, J., and van der Hoeven, J. S. Sulfate reducing bacteria in periodontal pockets and in healthy oral sites. Clin Periodontol. 1999; 26: 596-599

10. Willis, C. L., Gibson, G. R., Allison, C., MacFarlane, S., and Holt, J. S. Growth, incidence and activities of dissimilatory sulfate-reducing bacteria in the human oral cavity. FEMS Microbiology Letters. 1995; 129: $267-272$

11. Van der Hoeven, J. S., van den Kieboom, C. W., and Schaeken, M. J. Sulfate- reducing bacteria in the periodontal pocket. Oral Microbiol Immunol. 199510 (5): 288-290

12. Vianna, M. E., Holtgraewe, S., Seyfarth, I., Conrads, G., and Horz H. P. Quantitative Analysis of Three Hydrogenotrophic Microbial Groups, Methanogenic Archaea, Sulfate-Reducing Bacteria, and Acetogenic Bacteria, within Plaque Biofilms Associated with Human. Periodontal Disease Journal of Bacteriology. 2008; 190 (10): 37793785.

13. Langendijk, P. S., Kulik, E. M., Sandmeier, H., Meyer, J., and van der Hoeven, J. S. Isolation of Desulfomicrobium orale sp. nov. and Desulfovibrio strain NY682, oral sulfatereducing bacteria involved in human periodontal disease. International Journal of Systematic and Evolutionary Microbiology. 2001; 51: 1035-1044

14. Rao, T. S., Kora, A. J., Anupkumar, B. Narasimhan, S. V., and Feser, R. Pitting corrosion of titanium by a freshwater strain of sulphate reducing bacteria (Desulfovibrio vulgaris). Corrosion Science. 2005; 47 (50):1071-1084

15. Ringas, C., and Robinson, F.P.A. Corrosion of Stainless steel by Sulfate Reducing Bacteria - Total immersion test results. Corrosion. 1988; 44 (9): 671-673 